\title{
Illustration of the emerging capabilities of SARAL/AltiKa in the coastal zone using a multi-platform approach
}

\author{
Charles Troupin ${ }^{\mathrm{a}, \mathrm{d}, *}$, Ananda Pascual ${ }^{\mathrm{a}}$, Guillaume Valladeau ${ }^{\mathrm{b}}$, Isabelle \\ Pujol $^{\mathrm{b}}$, Arancha Lana ${ }^{\mathrm{a}}$, Emma Heslop ${ }^{\mathrm{a}}$, Simón Ruiz ${ }^{\mathrm{a}}$, Marc Torner ${ }^{\mathrm{d}}$, \\ Nicolas Picot ${ }^{\mathrm{c}}$, Joaquín Tintoréa,d \\ ${ }^{a}$ Mediterranean Institute for Advanced Studies (IMEDEA), Esporles, SPAIN \\ ${ }^{b}$ Collecte Localisation Satellites (CLS), Space Oceanography Division, Ramonville \\ Saint-Agne, FRANCE \\ ${ }^{c}$ Toulouse Space Centre (CST), Centre National d'Etudes Spatiales (CNES), Toulouse, \\ FRANCE \\ ${ }^{d}$ Balearic Islands Coastal Observing and Forecasting System (SOCIB), Palma de \\ Mallorca, SPAIN
}

\begin{abstract}
Satellite altimetry measurements from SARAL-AltiKa are analysed in the coastal ocean using the results of the G-AltiKa mission (1 to 5 August 2013), which combined altimeter, HF radar and glider data coincident with the satellite track, south-west of Ibiza Island, in the Western Mediterranean Sea.

The absolute dynamic topography, computed from $1 \mathrm{~Hz}$ and $40 \mathrm{~Hz}$ altimetry data, and the dynamic height, computed from glider temperature and salinity, both exhibited a weak signal with amplitudes of order $2 \mathrm{~cm}$. The resulting geostrophic and HF radar velocities along the track depicted a northwestward coastal current with a maximal velocity larger than $20 \mathrm{~cm} \mathrm{~s}^{-1}$.
\end{abstract}

\footnotetext{
*Corresponding author

Email addresses: ctroupin@socib.es (Charles Troupin), ananda.pascual@imedea.uib-csic.es (Ananda Pascual), guillaume.valladeau@cls.fr (Guillaume Valladeau), mpujol@cls.fr (Isabelle Pujol), alana@imedea.uib-csic.es (Arancha Lana), eheslop@imedea.uib-csic.es (Emma Heslop), simon.ruiz@imedea.uib-csic.es (Simón Ruiz), mtorner@socib.es (Marc Torner), Nicolas.Picot@cnes.fr (Nicolas Picot), jtintore@socib.es (Joaquín Tintoré)
} 
This demonstrates that the AltiKa altimeter is able to resolve SLA signals of more than $2 \mathrm{~cm}$, and gradients in those signals over several tens of kilometres. After filtering, the $40 \mathrm{~Hz}$ data depicted a signal consistent with the other platforms, up to a distance of order $10 \mathrm{~km}$ from the coast.

Keywords: Radar Altimetry, Meso-scale eddies, Ocean Gliders, North-western Mediterranean Sea, Ibiza Channel, HF radar, Satellite, Mediterranean oceanic currents, PEACHI

PACS: 92.10.ak, 92.10.Fj

\section{Introduction}

Over the last two decades, progresses in satellite altimetry and the establishment of a global network of profiling ARGO floats have contributed to revolutions in physical oceanography (Le Traon, 2013), enabling the global description of mesoscale processes in the open ocean. One of the main challenges of the present decade is the study of mesoscale processes, but in the coastal ocean. Such a challenge is addressed thanks to other revolutions in ocean observation: the recent improvements in coastal altimetry (Cipollini et al., 2010; Vignudelli et al., 2011), the intensive use of ocean gliders (Testor et al., 2010, Ruiz et al., 2012) and the development of high-frequency (HF) radar systems (Harlan et al., 2010).

The present work presents a cross-platform mission, G-AltiKa, performed south-west of Ibiza island (Balearic Sea, Western Mediterranean, Fig. 1) in August 2013, with the objectives of processing, validating and intercalibrating multi-platform measurements in the coastal ocean. G-AltiKa consists of a glider mission carried out along an AltiKa track, a new altimeter launched in February 2013 on board SARAL (SAtellite for ARgos and ALtiKa), and designed to measure the ocean surface topography with an unprecedented accuracy (Verron, 2013). The mission was designed to enable the blending of AltiKa altimetric data with multi-platform observation systems in order to examine small-scale dynamics in the Ibiza Channel. It benefited from a new observing component, not present in the previous multiplatforms missions in the same area, namely the coastal HF radar operated by the Balearic Islands Coastal Observing and Forecasting System (Tintoré et al., 2013).

The region studied is specially challenging because of the small values of the Internal Rossby Radius, of order $10 \mathrm{~km}$, with values sometimes lower than 
$5 \mathrm{~km}$, and because the oceanic processes cover a wide range of temporal and spatial scales (e.g., Gascard, 1991; Send et al., 1999; Bouché, 2003; Escudier et al., 2013). The interactions between these processes lead to intense subbasin scale dynamics, such as mesoscale eddies (Tintoré et al., 1990; Pinot et al., 1994, 2002; Rubio et al., 2009; Amores et al., 2013) or filaments (Wang et al., 1988; La Violette et al., 1990; Salusti, 1998; Bignami et al., 2008).

The considered altimeter track intersects with an important "choke" point in the basin scale circulation (Heslop et al., 2012), where two channels play a role in the meridional exchange of properties (heat and salt) between the Balearic and the Algerian sub-basins (García-Lafuente et al., 1995; Monserrat et al., 2008): the Ibiza Channel ( $80 \mathrm{~km}$ wide and $800 \mathrm{~m}$ maximum depth), which separates the Iberian Peninsula and Ibiza, and the Mallorca Channel, which separates Ibiza and Mallorca islands (Fig. 1). The warm, fresh Atlantic Water inflows occur mainly through the Ibiza Channel. The inflows are sometimes blocked by the presence of huge eddies with cold Western Intermediate Water cores (Pinot et al., 2002; Mason and Pascual, 2013), resulting in a north-east diversion of the Northern Current to join the Balearic Current, also described in numerical model outputs (Juza et al. 2013). Glider monitoring in the Ibiza Channel revealed high-frequency variability with changes of transport close to $1 \mathrm{~Sv}$ in less than one week (Heslop et al., 2012).

Multi-sensor approaches represent an efficient way to study and understand small-scale processes and vertical exchanges (e.g., Pascual et al., 2010, 2013). Recently, several missions using ship and glider measurements along with altimeter data have been carried out to enhance the description of smallscale dynamics in the Western Mediterranean Sea. Ruiz et al. (2009b) combined Jason-2 altimeter data with a glider section coincident with the satellite track to describe the subduction of a chlorophyll tongue in the Alboran Sea and diagnose the strong vertical velocity at the origin of the tongue. A similar technique was applied by Ruiz et al. (2009a), where glider and ship measurements were performed under an ENVISAT altimeter track, in order to provide a mesoscale description of the Balearic Front. Bouffard et al. (2010) further developed the combined approach by improving the processing/editing of satellite along-track measurements, thus reaching a better compatibility between glider and altimetry measurements, while Bouffard et al. (2012) employed a numerical model as an additional source of information for the multi-sensor comparison.

The present paper is focused on the G-AltiKa mission and the comparison of the observations provided by the various platforms. Section 2 de- 
scribes the measurement platforms, with a particular attention to the processing/filtering steps. The resulting currents are compared in Section 3 and the conclusions are presented in Section 4.

\section{Data and methods}

The G-AltiKa mission combined in situ data (glider) with remote-sensed measurements (satellite and HF radar). The different platforms are described below, while the various steps of data processing are presented in Sec. 2.4.

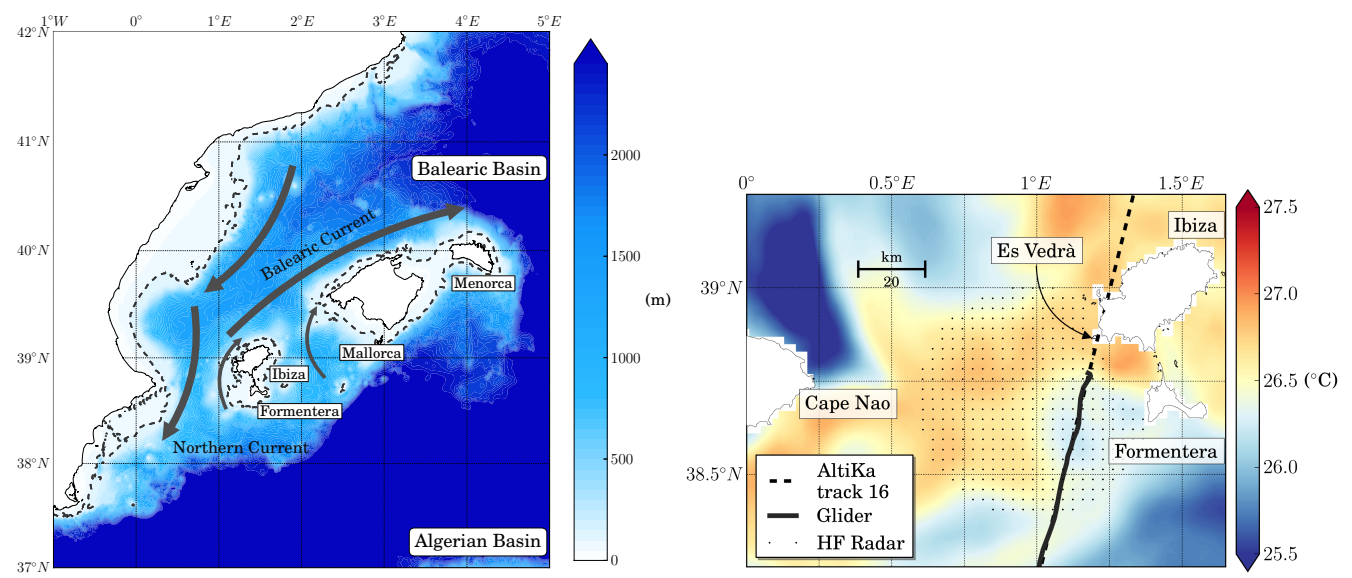

Figure 1: Study area and data. Left: main currents in the Balearic Sea. Right: HF radar, glider and altimetry data locations overlaid on the Ibiza Channel bathymetry.

\subsection{Altimetric data}

Altimetric data enable the computation of currents using the geostrophic balance, through the combination of along-track measurements of sea-level anomalies (SLA) with the Mean dynamic topography (MDT), which represents the stationary component of the ocean dynamic topography.

\subsubsection{Along-track sea-level anomalies}

SLA data are obtained by the AltiKa altimeter on board SARAL satellite. To ensure a long-term continuity of altimetry observations, SARAL ground track is almost the same as ENVISAT mission (European Space Agency), with an exact 35-day repeat cycle. AltiKa operates at a frequency in the Kaband $(35.75 \mathrm{GHz})$, leading to improved horizontal and spatial resolutions due 
to the reduced altimeter footprint and the enhanced bandwidth $(500 \mathrm{MHz})$, but at the cost of a higher sensitivity to rainy and cloudy conditions (Taveneau et al. 2011; Bronner, 2013).

The track no. 16 (Fig. 1) crossed part of Ibiza island on August 1, 2013, 18:26:12 UTC. The $1 \mathrm{~Hz}$ altimeter data (one value every $7 \mathrm{~km}$ on average) used in this study correspond to the Ssalto/DUACS NRT products, the processing of which is fully described in Dibarboure et al. (2011) and in the user handbook (DUA, 2014). The 40-Hz measurements (one value every $174 \mathrm{~m}$ on average) were obtained from the Archiving, Validation and Interpretation of Satellite Oceanographic Data system (AVISO) after their processing with the Prototype for Expertise on AltiKa for Coastal Hydrology and Ice (PEACHI). The prototype relies on AltiKa level-1b Sensor Geophysical Data Record (SGDR) products, where most of the altimeter parameters are processed within the acquisition procedure, especially the $40 \mathrm{~Hz}$ waveforms required for retracking and a high precision orbit (accuracy on the order of $2.5 \mathrm{~cm}$ ). Like Jason-2, instruments on SARAL/AltiKa perform direct observations of the following parameters: altimeter range, significant wave height, ocean radar backscatter cross-section as a measure of wind speed, ionospheric electron content, tropospheric water content, mean sea surface, and position relative to the GPS satellite constellation. The S-GDR data thus contain all the relevant corrections required to compute the sea surface height. As S-GDR products are released 35 days after AltiKa data records, the PEACHI prototype also consists of the acquisition of the Interim Sensor Geophysical Data Record (S-IGDR) products to complete the whole altimeter time series in near real time, with the aim of providing the latest measurements processed within the prototype. Thus, the PEACHI prototype aims at improving the reliability and the accuracy of the geophysical parameters and therefore Ka altimeter measurements thanks to the new or improved algorithms.

\subsubsection{Mean dynamic topography}

The mean dynamic topography (MDT) represents the long-term-average circulation. The sum of the MDT and the SLA produces the absolute dynamic topography (ADT), from which the absolute geostrophic velocity is derived using the geostrophic equations. For the Mediterranean Sea, the MDT developed by Rio et al. (2014) (SMDT-MED-2014) is used. SMDTMED-2014 was constructed with the same method as in Rio et al. (2007), but with updated datasets of drifter velocities and hydrological profiles. The spatial resolution is $0.0625^{\circ}$ by $0.0625^{\circ}$, versus $0.125^{\circ}$ by $0.125^{\circ}$ for the previous 
version.

\subsection{Glider}

A deep Slocum glider was deployed on August 2, 2013, 09:20:57 UTC, at $38.190^{\circ} \mathrm{N}, 0.995^{\circ} \mathrm{E}$, south-west of Ibiza island, approximatively on AltiKa track no. 16. The transect ended on August 5, 2013, 01:38:51 UTC, at $38.778^{\circ} \mathrm{N}, 1.160^{\circ} \mathrm{E}$ after a $74 \mathrm{~km}$ course.

The glider was equipped with a SeaBird Pumped CTD, a fluorometer (WetLabs FLNTU) and an oxygen sensor (Aanderaa Oxygen Optode 4330F). A total of 253 profiles (126 downcast and 127 upcast) were acquired. The horizontal resolution (distance between two consecutive surfacings) is related to the local depth, which varied from $975 \mathrm{~m}$ to $90 \mathrm{~m}$, at the location closest to the coast (about $10 \mathrm{~km}$, Es Vedrà island). In the deepest areas, the resolution was approximatively $5 \mathrm{~km}$, while approaching the coast, it decreased to less than $1 \mathrm{~km}$.

In addition to the temperature and salinity profiles, the depth-averaged velocity (DAV, Fig. 2) can be estimated using the glider positioning system (GPS) as follows: the glider makes a calculation of the current experienced since its last surfacing from the difference between both estimated (dead reckoned position from heading and velocity) and its current actual location from GPS. The DAV depends on the accuracy of the on-board compass, to which a mission specific error calibration was applied (Merckelbach et al. 2008).

\subsection{HF radar}

The SOCIB SeaSonde HF radar system by Coastal ocean dynamics applications radar (CODAR), is formed by two stations, each consisting of a three-antenna element. The stations are located on Ibiza and Formentera islands, with the objective of monitoring the surface circulation in the eastern part of the Ibiza Channel (Fig. 1). The radar system operates at a frequency of $13.5 \mathrm{MHz}$ with a $90-\mathrm{kHz}$ bandwidth and provides surface currents on a $3 \mathrm{~km}$-resolution grid at hourly intervals, with a range up to $74 \mathrm{~km}$ (40 nautical miles) offshore. The southernmost latitude covered by the radar system is $38.050^{\circ} \mathrm{N}$, so that $63 \%$ of the glider trajectory was inside the radar range. In some cases, radial velocities have been shown to provide better results in quantitative comparison (e.g., Liu et al., 2012), however in this work total currents were used because they offer both velocity components. 


\subsection{Data processing}

\subsubsection{Computation of dynamic height}

The dynamic height (DH) is obtained by integrating the density, calculated from the glider temperature and salinity, between a level of reference and the surface. Tests with reference levels chosen between 300 and $900 \mathrm{~m}$ evidenced a weak sensitivity of DH gradients to this parameter. Similar conclusions were drawn with glider measurements from another mission north of Mallorca (Ruiz et al., 2009a), in agreement with previous regional studies, which have shown that upper ocean $(0-300 \mathrm{~m})$ slope currents dominate the dynamics.

\subsubsection{Spatial interpolation}

With the objective of performing the platform comparisons on a common track, the MDT, 1-Hz SLA, glider DH and HF radar velocities were resampled onto the measurement locations of the $40 \mathrm{~Hz}$ satellite track, using linear interpolation. The goal was to obtain the data on a unique set of locations, so the simplest interpolation method was preferred. No extrapolation was performed because of the risk of artificially generating large gradients of SLA, and thus large velocities. The ADT was obtained by adding the interpolated MDT and SLA.

\subsubsection{Filtering}

In order to get rid of inertial motions and high-frequency processes not compatible with the hypothesis of geostrophy, a windowed sinc filter (e.g., Smith, 2002) with a 30-hour cut-off and a Blackman window (Blackman and Tukey, 1959) was applied to the HF radar data. A similar filter, but with a 14-km cut-off, was applied to the altimeter and glider data. The $14 \mathrm{~km}$ cut-off is in line with the values used in similar studies (e.g., Bouffard et al. 2010, 2012). A weak sensitivity to the cut-off length was observed. The windowed sinc filter was selected because of its good stop-band attenuation and low pass-band ripple. Other filter windows were tested but the resulting signals did not exhibit significant differences. The filters were designed using the Scipy Signal Processing Module (Jones et al., 2001).

\subsubsection{Geostrophic velocity computation}

The component of the geostrophic current perpendicular to the satellite track is obtained by the geostrophy equations, which amounts to computing 
spatial derivatives. The geostrophic currents are computed by applying central finite differences in the interior and first differences at the boundaries on the filtered and unfiltered $1 \mathrm{~Hz}$ SLA, filtered $40 \mathrm{~Hz}$ SLA and glider DH. With this scheme, one point at the boundary is lost. No additional filtering or smoothing was applied to the SLA prior to the velocity derivation. The unfiltered $40 \mathrm{~Hz}$ signal led to unrealistic velocities, which were therefore not considered in the subsequent discussions.

\subsubsection{Correction to glider velocities}

The depth-averaged absolute currents retrieved from the GPS glider positioning (Sec. 2.2) were used to correct the surface geostrophic current, following the method described in Bouffard et al. (2012). The difference between the relative depth-averaged geostrophic currents (computed from DH) and the absolute DAV (computed from glider GPS) constitutes a reliable estimation of the absolute geostrophic current at the reference level. Hence if this velocity difference is added to the relative geostrophic current at each depth level, the absolute geostrophic current is obtained. As altimetry provides the component normal to the track, only the perpendicular component of the DAV is added to the correction.

The condition for this correction to be valid is that the vertically averaged horizontal ageostrophic velocity is negligible with respect to the DAV. Bouffard et al. (2010) showed that barotrophic high-frequency motion, tidal or Ekman currents constitute negligible contributions in the study area. Scatterometer satellite data (not shown) confirmed the weak wind intensity in the studied area. Note that the assumption regarding the ageostrophic component of the velocity is fulfilled for our study region, but is not automatically satisfied in all the coastal regions, for instance across the West Florida Shelf (e.g., Liu and Weisberg, 2007).

\section{Results}

Because of the low number of degrees of freedom (between 3 and 5), the correlations computed between the signals of the different platforms are not statistically significant. For this reason, the current section is focused on a qualitative description of the features obtained after the data processing.

\subsection{Glider temperature and depth-average velocity}

The glider sampled the whole water column with a high-resolution, especially in the coastal area (the last $20 \mathrm{~km}$ of the track) and evidenced the 
strong stratification, characteristic of the region in summer months (Fig. 2). Temperature close to the surface was above $26^{\circ} \mathrm{C}$.

The estimated DAV ranged from $2 \mathrm{~cm} \mathrm{~s}^{-1}$ in the southernmost part of the glider trajectory to $10 \mathrm{~cm} \mathrm{~s}^{-1}$ near the end point, with a preferred northwestward orientation.
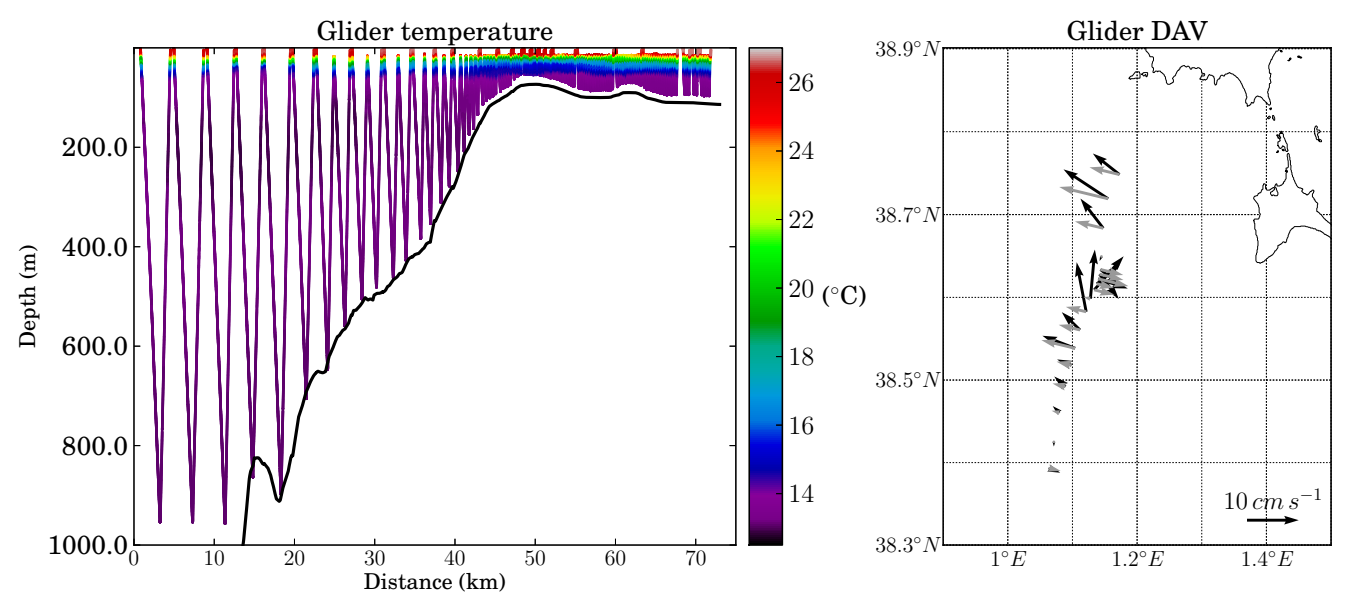

Figure 2: Temperature measurements along the glider track (left) and depth-averaged velocities. The normal component is shown in grey

\subsection{Dynamic height and absolute dynamic topography}

The glider DH and the ADT at $1 \mathrm{~Hz}$ and $40 \mathrm{~Hz}$ obtained with the processing described in the previous section, are shown in Fig. 3. The first observation is the weak amplitudes $(\approx 2 \mathrm{~cm})$ and gradients present all along the track. Such values are close to the accuracy expected for the SLA measurements by SARAL/AltiKa and illustrate the weak dynamic activity at this time of the year. Along the glider trajectory, the MDT (not shown) ranges from $-1 \mathrm{~cm}$ at $38.2^{\circ} \mathrm{N}$ to $0 \mathrm{~cm}$ close to the island at $38.78^{\circ} \mathrm{N}$. However these variations have to be taken into account, given the weak amplitude of along-track SLA.

The three filtered curves have in common the $2-4 \mathrm{~cm}$ rise in the northern part of the track, which is associated to a north-westward current (see next section). Another relevant feature is the apparent shift, on the order of $5 \mathrm{~km}$, between the different filtered curves. The shift is easily identifiable by observing the local minima and maxima between 38.5 and $38.7^{\circ} \mathrm{N}$. This shift can be attributed to the lack of synopticity between the measurements: the 
glider was deployed about 17 hours after the altimeter pass, but the end of the trajectory took place more than 3 days after the satellite pass (Sec. 2.2).

As the spatial extension of the common segment of data is limited, it is not possible to perform a fully consistent statistical assessment when comparing the various datasets. However, a qualitative description of the features obtained after data processing will be made hereafter.

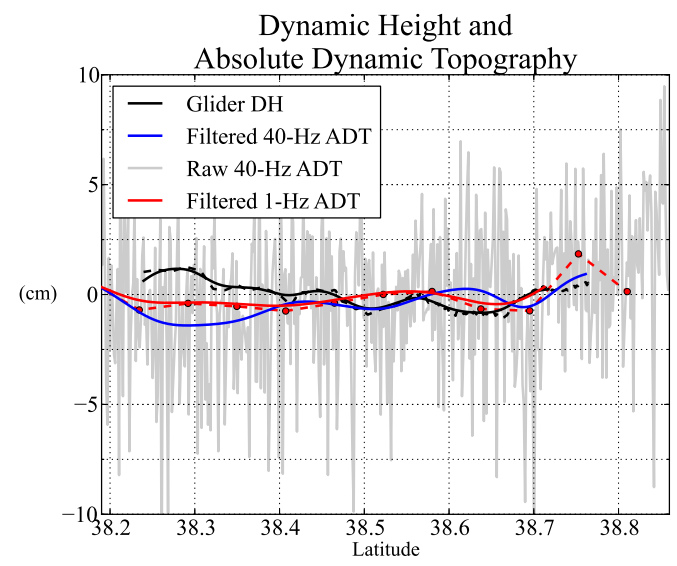

Figure 3: Absolute dynamic topography and dynamic height along SARAL track no. 16 southwest of Ibiza islands. Dashed lines represent the unfiltered glider DH and $1 \mathrm{~Hz}$ ADT signals.

\subsection{Time variability and spatial structure}

It is instructive to examine the spatial structure and the temporal variability of the currents over the duration of the mission, since the along-track data do not allow a description of the two-dimensional surface structures. To this end, HF radar velocity fields corresponding to August 2, 12:00, August 3, 18:00 and August 5, 00:00, are presented (Fig. 4). On August 2, currents described a cyclonic circulation (red arrows in the figure) centred at $38.65^{\circ} \mathrm{N}, 0.9^{\circ} \mathrm{E}$; the strongest currents, located south-west of Ibiza, were dominantly north-westward with a velocity on the order of $20 \mathrm{~cm} \mathrm{~s}^{-1}$ and a jet width of approximatively $20 \mathrm{~km}$. In the southern part of the HF radar area, the velocity was mostly eastward. On August 3, the cyclonic circulation persisted and intensified; the center moved slightly south-westward and the north-westward jet increased its width to more than $25 \mathrm{~km}$. The circulation west of Ibiza, above $38.8^{\circ} \mathrm{N}$, also changed, with the development of an anticyclonic circulation centred west of Ibiza with a $10 \mathrm{~km}$ radius and velocities 
greater than $25 \mathrm{~cm} \mathrm{~s}^{-1}$. On August 5, both the anticyclonic and the cyclonic structures remain, with their respective center slightly displaced.

The cross-track velocities (Fig. 4, black area around the satellite track) evidence the evolution of circulation, in particular the overall cyclonic circulation maintained through the G-AltiKa mission and the displacements of the circulation center.
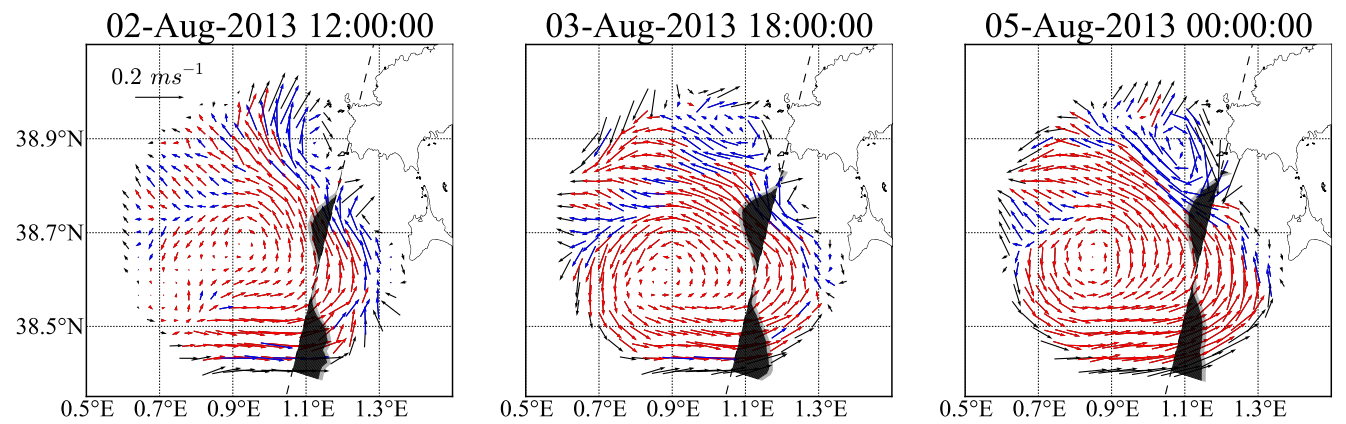

Figure 4: HF Radar velocities on August 2, 12:00, August 3, 18:00 and August 5, 0:00. Red arrows indicate positive vorticity. The velocity component perpendicular to SARAL/AltiKa track (dashed line) is plotted in black.

\subsection{Velocity structure}

The geostrophic velocities derived from the ADT $(1 \mathrm{~Hz}$ and $40 \mathrm{~Hz})$ and the DH are compared to the HF radar velocities (Fig. 5). Velocities calculated using the smoothed $1-\mathrm{Hz}$ data show consistencies with the pattern of crosstrack velocities from the HF Radar and filtered glider DH, as all three have a zero-crossing at about $38.65^{\circ} \mathrm{N}$ and flow to the west north of that latitude.

Both the $\mathrm{HF}$ radar and the $1 \mathrm{~Hz}$ data (top sub-figures) depict the cyclonic circulation described in the previous section and exhibit similar maximal velocities. However, south of $38.55^{\circ} \mathrm{N}$, the two platforms provide velocities in opposite directions. These discrepancies may be attributed to several factors: the $6 \mathrm{~km}$ radius for the radial velocity smoothing, the vertical shear (HF radar velocities are not measured exactly at the surface), or the temporal averaging (e.g., Liu et al., 2014). Also, the typical error of HF radar velocities is of order $10 \mathrm{~cm} \mathrm{~s}^{-1}$, depending, among other issues, on the HF radar system, on the current geometry, as well as on waves and weather conditions (e.g., Chapman et al., 1997; Yoshikawa et al., 2006; Roesler et al., 2013). Results south of $38.65^{\circ} \mathrm{N}$ have to be considered with caution since the variability in 
heights is below the $2 \mathrm{~cm}$ range (Fig. 3), which is the expected accuracy of AltiKa.

The $40 \mathrm{~Hz}$ and the glider data (Fig. 5, bottom sub-figures) offer an increased spatial resolution of the features. The dominant westward current in the upper part of the track (north of $38.65^{\circ} \mathrm{N}$ ) is well reproduced by both platforms, with comparable maximal velocities and a similar current structure. Overall, the results north of $38.65^{\circ} \mathrm{N}$ display a correct magnitude. South of that latitude, The $40-\mathrm{Hz}$ altimeter and the glider data produced more smallscale features than the $\mathrm{HF}$ radar and the $1 \mathrm{~Hz}$ data (four alternating jets south of the zero-crossing), but the weakness of the signals does not allow us to indicate what structure is the most realistic.

The HF radar platform provides data closest to the coast, about $3 \mathrm{~km}$. After applying the filter, high-resolution altimetric data yield geostrophic currents at a distance close to $10 \mathrm{~km}$ from land. Concerning the glider, safety considerations come into consideration when deciding the final location of the deployment.

Additional information from satellites (sea surface temperature, Fig. 1, right panel; chlorophyll concentration, not shown) are not able to resolve the small-scale features visible in the southern part of the track. However, SST seems to depict the signature of a cyclonic eddy, centred on approximately $38.6^{\circ} \mathrm{N}, 1.15^{\circ} \mathrm{E}$, with a jet on its north-eastern part, consistent with the measurements along the satellite track and with $\mathrm{HF}$ radar data.

\section{Discussion and conclusions}

The description of mesoscale processes in the coastal area using observations constitutes a new challenge in oceanography in the current decade, and this challenge has to be tackled by a multi-platform approach. The work presented here is focused on the coastal area south-west of Ibiza, in the Balearic Sea.

The measurements from in situ (glider) and remote-sensed (HF radar, altimeter) platforms acquired between August 1 and 5, 2013, south-west of Ibiza, were processed in order to provide the velocity along the SARAL/AltiKa track. Despite the weak gradients, close to the AltiKa expected accuracy, observed in the DH and ADT signals, all the platforms showed the existence of a north-westward coastal current less than $20 \mathrm{~km}$ off Ibiza, with an intensity exceeding $20 \mathrm{~cm} \mathrm{~s}^{-1}$. Further offshore, the velocity structures obtained 
from the different platforms have to be considered with caution because of the weak variability in heights.

The differences observed between $1-\mathrm{Hz}$ and $40-\mathrm{Hz}$ data are due to different factors. Firstly, the differences in resolution: part of the sub-mesoscale structures present in the high resolution product cannot be fully resolved with a $1-\mathrm{Hz}$ resolution. Secondly, the use of a mean profile (MP, an along-track mean sea surface), which is part of the improved processing of the DUACS system: the mean profile accuracy is improved with respect to a gridded Mean Sea Surface (MSS). This processing is not included in the $40-\mathrm{Hz}$ measurements. The differences between the MP and the less precise gridded MSS are of order of few millimetres and can reach up to $1 \mathrm{~cm}$. The computation and use of the MP imply that the altimeter measurements are interpolated on static theoretical positions, which can lead to additional differences. Finally, the wet troposphere correction is responsible for a difference of a few millimetres $(<3 \mathrm{~mm})$ between $1-\mathrm{Hz}$ and $40-\mathrm{Hz}$ data: the radiometer solution is used in the case of the $1-\mathrm{Hz}$ measurement, while ECMWF model solution is used for $40-\mathrm{Hz}$ products. The agreement between low and high resolution altimetric product would certainly be improved, if the same MSS and the radiometer wet troposphere correction were applied to both types of data.

Though the presented work is focused on the surface velocities, the complementary virtue of the different components of the observing system is clear: the SLA data from SARAL/Altika, combined with the Mediterranean Sea MDT, offer a detailed representation of the cross-track current. In particular, these data allow one to derive the geostrophic velocity about $10 \mathrm{~km}$ from the coast, which was not possible in earlier altimetry missions. On the other hand, the glider has the unique capability of profiling the water column with an horizontal resolution below $1 \mathrm{~km}$. The HF radar system has the unique capacity to combine an extended spatial coverage (more than $70 \mathrm{~km}$ offshore) with a temporal resolution of 1 hour. It is thus the most adequate tool with which to address the possible synopticity issue between the altimeter and the glider data. In addition to its numerous uses in oceanography (search and rescue, assimilation in numerical model, ...), this is also the platform that provides the data closest to land, approximatively $3 \mathrm{~km}$. Finally, the three platforms have in common that they are highly robust systems able to monitor hydrographic conditions in the study area, even under adverse meteorological conditions.

All in all, this initial validation/inter-comparison exercise is of particular value in assessing the quality of SARAL/AltiKa data in the coastal band. 
It also emphasizes the relevance of cross-platform approaches in the study of the coastal ocean dynamics and of the additional sources of validation for the currents (drifters for example) and the necessity to acquire in situ measurements closer to the coast in future studies in order to confirm the velocities deduced from high-resolution altimetry.

\section{Acknowledgements}

SARAL IGDR are produced by CNES SPA Team as part of the SSALTO ground processing segment, and distributed by AVISO, with support from CNES SALP project. G-AltiKa experiment was carried out in the frame of MyOcean2 EU FP7 funded project, with substantial support from SOCIB. Glider operations were partially funded by JERICO and PERSEUS FP7 projects. The authors would like to extend special thanks to S. Cusí, C. Castilla, I. Lizarán and the SOCIB data centre for their efficient work during G-AltiKa experiment, and to C. Pelloquin (CLS) for providing us with the near-real time data. Additional funding from the Local Government of the Balearic Islands (CAIB-51/2011 Grant) is also acknowledged. C. Troupin post-doctoral position was funded by MyOcean2 EU FP7 project. This work is a contribution to the SARAL/AltiKa science team.

\section{References}

, 2014. SSALTO/DUACS User Handbook: (M)SLA and (M)ADT Near-Real Time and Delayed Time Products.

Amores, A., Monserrat, S., Marcos, M., 2013. Vertical structure and temporal evolution of an anticyclonic eddy in the Balearic Sea (western Mediterranean). J. Geophys. Res. 118, 2097-2106. doi:10.1002/jgrc.20150.

URL: http://onlinelibrary.wiley.com/doi/10.1002/jgrc.20150/ abstract

Bignami, F., Böhm, E., D’Acunzo, E., D’Archino, R., Salusti, E., 2008. On the dynamics of surface cold filaments in the Mediterranean Sea. J. Mar. Syst. 74, 429-442. doi:10.1016/j.jmarsys.2008.03.002.

URL: http://wWw.sciencedirect.com/science/article/pii/ S0924796308000547 
Blackman, R.B., Tukey, J.W., 1959. The Measurement of Power Spectra, From the Point of View of Communications Engineering. Dover, New York. ISBN: 978-0486605074.

Bouché, V., 2003. About process times in some deepwater formation events in the Mediterranean Sea. J. Mar. Syst. 38, 305-321. doi: 10.1016/S0924-7963(02)00249-X.

URL: http://www.sciencedirect.com/science/article/pii/ S092479630200249X

Bouffard, J., Pascual, A., Ruiz, S., Faugère, Y., Tintoré, J., 2010. Coastal and mesoscale dynamics characterization using altimetry and gliders: A case study in the Balearic Sea. J. Geophys. Res. 115, . doi:10.1029/ 2009JC006087.

URL: http://www .agu.org/pubs/crossref/2010/2009JC006087.shtml

Bouffard, J., Renault, L., Ruiz, S., Pascual, A., Dufau, C., Tintoré, J., 2012. Sub-surface small-scale eddy dynamics from multi-sensor observations and modeling. Prog. Oceanogr. 106, 62-79. doi:10.1016/j.pocean.2012.06.007.

URL: http://www.sciencedirect.com/science/article/pii/ S0079661112000705

Bronner, E., 2013. SARAL/AltiKa Products Handbook. Technical Report Issue 2 rev. 3. CNES. 87 pp.

Chapman, R.D., Shay, L.K., Graber, H.C., Edson, J.B., Karachintsev, A., Trump, C.L., Ross, D.B., 1997. On the accuracy of hf radar surface current measurements: Intercomparisons with ship-based sensors. J. Geophys. Res. 102, 18737-18748. doi:10.1029/97JC00049.

URL: http://onlinelibrary.wiley.com/doi/10.1029/97JC00049/ abstract

Cipollini, P., Beneviste, J., Bouffard, J., Emery, W., Fenoglio-Marc, L., Gommenginger, C., Griffin, D., Hoyer, J., Kurapov, A., Madsen, K., Mercier, F., Miller, L., Pascual, A., Ravichandran, M., Shillington, F., Snaith, H., Strub, T., Vandemark, D., Vignudelli, S., Wilkin, J., Woodworth, P., Zavala-Garay, J., 2010. The role of altimetry in coastal observing systems. in: Hall, J., Harrison, D., Stammer, D. (Eds.), Proceedings of OceanObs'09: Sustained Ocean Observations and Information for Society, 
Vol. 2. European Space Agency. WPP-306, pp. 181-191.

URL: http://eprints.soton.ac.uk/340378/

Dibarboure, G., Pujol, M.I., Briol, F., Traon, P.Y.L., Larnicol, G., Picot, N., Mertz, F., Ablain, M., 2011. Jason-2 in DUACS: Updated System Description, First Tandem Results and Impact on Processing and Products. Mar. Geod. 34, 214-241. doi:10.1080/01490419.2011.584826.

URL: http://www.tandfonline.com/doi/pdf/10.1080/01490419. 2011.584826\#.U7qKqXLgwYw

Escudier, R., Bouffard, J., Pascual, A., Poulain, P.M., Pujol, M.I., 2013. Improvement of coastal and mesoscale observation from space: application to the Northwestern Mediterranean Sea. Geophys. Res. Lett. 40, 21482153. doi:10.1002/grl.50324.

URL: http://onlinelibrary.wiley.com/doi/10.1002/grl.50324/pdf

García-Lafuente, J.M., López-Jurado, J.L., Cano-Lucaya, N., Vargas-Yáñez, M., Aguiar-Garcia, J., 1995. Circulation of water masses through the Ibiza Channel. Oceanol. Acta 18, 245-254.

Gascard, J.C., 1991. Open Ocean Convection and Deep Water Formation Revisited in the Mediterranean, Labrador, Greenland and Weddell Seas. in: Chu, P., Gascard, J.C. (Eds.), Deep Convection and Deep Water Formation in the Oceans Proceedings of the International Monterey Colloquium on Deep Convection and Deep Water Formation in the Oceans. Elsevier. volume 57 of Elsevier Oceanography Series, pp. 157-181. doi:10.1016/S0422-9894(08)70066-7.

URL: http://www.sciencedirect.com/science/article/pii/ S0422989408700667

Harlan, J., Terrill, E., Hazard, L., Keen, C., Barrick, D., Whelan, C., Howden, S., Kohut, J., 2010. The integrated ocean observing system high-frequency radar network: Status and local, regional, and national applications. Mar. Technol. Soc. J. 44, 122-132. doi:10.4031/mtsj.44.6.6.

URL: http://www.ingentaconnect.com/content/mts/mts j/2010/ 00000044/00000006/art00017

Heslop, E.E., Ruiz, S., Allen, J., López-Jurado, J.L., Renault, L., Tintoré, J., 2012. Autonomous underwater gliders monitoring variability at choke points in our ocean system: A case study in the Western Mediterranean 
Sea. Geophys. Res. Lett. 39, L20604. doi:10.1029/2012GL053717.

URL: http://onlinelibrary.wiley.com/doi/10.1029/2012GL053717/ full

Jones, E., Oliphant, T., Peterson, P., et al., 2001. SciPy: Open source scientific tools for Python.

Juza, M., Renault, L., Ruiz, S., Tintoré, J., 2013. Origin and pathways of Winter Intermediate Water in the Northwestern Mediterranean Sea using observations and numerical simulation. J. Geophys. Res. 118, 6621-6633. doi:10.1002/2013JC009231.

URL: http://onlinelibrary.wiley.com/doi/10.1002/2013JC009231/ full

La Violette, P.E., Tintoré, J., Font, J., 1990. The surface circulation of the Balearic Sea. J. Geophys. Res. 95, 1559-1568. doi: 10.1029/JC095iC02p01559.

URL: $\quad$ http://onlinelibrary.wiley.com/doi/10.1029/ JC095iC02p01559/pdf

Le Traon, P.Y., 2013. From satellite altimetry to Argo and operational oceanography: three revolutions in oceanography. Ocean Sci. 9, 901-915. doi:10.5194/os-9-901-2013.

URL: http://www.ocean-sci.net/9/901/2013/

Liu, Y., Weisberg, R.H., 2007. Ocean Currents and Sea Surface Heights Estimated across the West Florida Shelf. J. Phys. Oceanogr. 37, 16971713. doi:10.1175/jpo3083.1.

URL: http://journals .ametsoc.org/doi/abs/10.1175/JP03083.1

Liu, Y., Weisberg, R.H., Merz, C.R., 2014. Assessment of CODAR SeaSonde and WERA HF Radars in Mapping Surface Currents on the West Florida Shelf. J. Atmos. Oceanic Tech. 31, 1363-1382. doi: 10.1175/jtech-d-13-00107.1.

URL: $\quad$ http://journals .ametsoc.org/doi/abs/10.1175/ JTECH-D-13-00107.1

Liu, Y., Weisberg, R.H., Vignudelli, S., Roblou, L., Merz, C.R., 2012. Comparison of the X-TRACK altimetry estimated currents with moored ADCP and HF radar observations on the West Florida Shelf. Adv. Space 
Res. 50, 1085-1098. doi:10.1016/j.asr.2011.09.012.

URL: http://wwW.sciencedirect.com/science/article/pii/ S0273117711006776

Mason, E., Pascual, A., 2013. Multiscale variability in the Balearic Sea: An altimetric perspective. J. Geophys. Res. 118, 3007-3025. doi: 10.1002/jgrc.20234.

URL: http://onlinelibrary.wiley.com/doi/10.1002/jgrc.20234/ abstract

Merckelbach, L., Briggs, R.D., Smeed, D., Griffiths, G., 2008. Current measurements from autonomous underwater gliders. in: Current Measurement Technology, 2008. CMTC 2008. IEEE/OES 9th Working Conference on Measurement Technology, Inst. Electr. Eng., Piscataway. pp. 61-67. doi: 10.1109/CCM.2008.4480845.

Monserrat, S., López-Jurado, J., Marcos, M., 2008. A mesoscale index to describe the regional circulation around the Balearic Islands. J. Mar. Syst. 71, 413 - 420. doi:10.1016/j.jmarsys.2006.11.012.

URL: http://wWw.sciencedirect.com/science/article/pii/ S0924796307002011

Pascual, A., Bouffard, J., Ruiz, S., Buongiorno Nardelli, B., Vidal-Vijande, E., Escudier, R., Sayol, J.M., Orfila, A., 2013. Recent improvements in mesoscale characterization of the western Mediterranean Sea: synergy between satellite altimetry and other observational approaches. Sci. Mar. 77, 19-36. doi:10.3989/scimar.03740.15A.

URL: http://www.icm.csic.es/scimar/index.php/secId/6/IdArt/ $4179 /$

Pascual, A., Ruiz, S., Tintoré, J., 2010. Combining new and conventional sensors to study the Balearic Current. Sea Technol. 51, 32-36.

URL: http://www.sea-technology.com/features/2010/0710/ balearic_current.html

Pinot, J.M., López-Jurado, J., Riera, M., 2002. The CANALES experiment (1996-1998). Interannual, seasonal, and mesoscale variability of the circulation in the Balearic Channels. Prog. Oceanogr. 55, 335-370. doi:10.1016/S0079-6611(02)00139-8. 
URL: http://www.sciencedirect.com/science/article/pii/ S0079661102001398

Pinot, J.M., Tintoré, J., Gomis, D., 1994. Quasi-synoptic mesoscale variability in the Balearic Sea. Deep-Sea Res. I 41, 897 - 914. doi: 10.1016/0967-0637(94)90082-5.

URL: http://www.sciencedirect.com/science/article/pii/ 0967063794900825

Rio, M.H., Pascual, A., Poulain, P.M., Menna, M., Barceló, B., Tintoré, J., 2014. Computation of a new mean dynamic topography for the Mediterranean Sea from model outputs, altimeter measurements and oceanographic in situ data. Ocean Sci. 10, 731-744. doi:10.5194/os-10-731-2014. URL: http://www.ocean-sci.net/10/731/2014/os-10-731-2014. html

Rio, M.H., Poulain, P.M., Pascual, A., Mauri, E., Larnicol, G., Santoleri, R., 2007. A Mean Dynamic Topography of the Mediterranean Sea computed from altimetric data, in-situ measurements and a general circulation model. J. Mar. Syst. 65, 484-508. doi:10.1016/j.jmarsys.2005.02.006.

URL: http://wWw.sciencedirect.com/science/article/pii/ S0924796306003083

Roesler, C.J., Emery, W.J., Kim, S.Y., 2013. Evaluating the use of high-frequency radar coastal currents to correct satellite altimetry. J. Geophys. Res. 118, 3240-3259. doi:10.1002/jgrc.20220.

URL: http://onlinelibrary.wiley.com/doi/10.1002/jgrc.20220/ full

Rubio, A., Barnier, B., Jordà, G., Espino, M., Marsaleix, P., 2009. Origin and dynamics of mesoscale eddies in the Catalan Sea (NW Mediterranean): Insight from a numerical model study. J. Geophys. Res. 114, C06009. doi: 10.1029/2007JC004245.

URL: http://onlinelibrary.wiley.com/doi/10.1029/2007JC004245/ full

Ruiz, S., Garau, B., Martnez-Ledesma, M., Casas, B., Pascual, A., Vizoso, G., Bouffard, J., Heslop, E., Alvarez, A., Testor, P., Tintoré, J., 2012. New technologies for marine research: five years of glider activities at IMEDEA. Sci. Mar. 76, 261270. doi:10.3989/scimar.03622.191. 
URL: http://scientiamarina.revistas.csic.es/index.php/ scientiamarina/article/view/1372/1471

Ruiz, S., Pascual, A., Garau, B., Faugère, Y., Alvarez, A., Tintoré, J., 2009a. Mesoscale dynamics of the Balearic Front, integrating glider, ship and satellite data. J. Mar. Syst. 78 (supplement), S3-S16. doi: 10.1016/j.jmarsys.2009.01.007. URL: http://wWw.sciencedirect.com/science/article/pii/ S0924796309001365

Ruiz, S., Pascual, A., Garau, B., Pujol, I., Tintoré, J., 2009b. Vertical motion in the upper ocean from glider and altimetry data. Geophys. Res. Lett. 36, L14607. doi:10.1029/2009GL038569.

URL: http://www .agu.org/pubs/crossref/2009/2009GL038569. shtml

Salusti, E., 1998. Satellite images of upwellings and cold filament dynamics as transient effects of violent air-sea interactions downstream from the island of Sardinia (western Mediterranean Sea). J. Geophys. Res. 103, 3013-3031. doi:10.1029/97JC01914.

URL: http://onlinelibrary.wiley.com/doi/10.1029/97JC01914/ abstract

Send, U., Font, J., Krahmann, G., Millot, C., Rhein, M., Tintoré, J., 1999. Recent advances in observing the physical oceanography of the western Mediterranean Sea. Prog. Oceanogr. 44, 37-64. doi: 10.1016/S0079-6611(99)00020-8.

URL: http://www.sciencedirect.com/science/article/pii/ S0079661199000208

Smith, S., 2002. Digital Signal Processing: A Practical Guide for Engineers and Scientists. California Technical Publishing. 1st edition. ISBN: 9780750674447.

URL: http://www.dspguide.com/

Taveneau, N., Robert, F., Richard, J., Steunou, N., Sengenes, P., 2011. Characteristics and performances of the AltiKa radiometer of SARAL mission. in: Geoscience and Remote Sensing Symposium (IGARSS), 2011 IEEE International, pp. 3979-3982. doi:10.1109/IGARSS.2011.6050103. 
Testor, P., Meyers, G., Pattiaratchi, C., Bachmayer, R., Hayes, D., Pouliquen, S., de la Villeon, L.P., Carval, T., Ganachaud, A., Gourdeau, L., Mortier, L., Claustre, H., Taillandier, V., Lherminier, P., Terre, T., Visbeck, M., Karstensen, J., Krahman, G., Alvarez, A., Rixen, M., Poulain, P.M., Osterhus, S., Tintore, J., Ruiz, S., Garau, B., Smeed, D., Griffiths, G., Merckelbach, L., Sherwin, T., Schmid, C., Barth, J.A., Schofield, O., Glenn, S., Kohut, J., Perry, M.J., Eriksen, C., Send, U., Davis, R., Rudnick, D., Sherman, J., Jones, C., Webb, D., Lee, C., Owens, B., 2010. Gliders as a Component of Future Observing Systems. in: Hall, J., Harrison, D., Stammer, D. (Eds.), Proceedings of OceanObs'09: Sustained Ocean Observations and Information for Society, Vol. 2. European Space Agency. doi:10.5270/oceanobs09.cwp.89.

URL: http://www.oceanobs09.net/proceedings/cwp/cwp89/index. php

Tintoré, J., Vizoso, G., Casas, B., Heslop, E., Pascual, A., Orfila, A., Ruiz, S., Martínez-Ledesma, M., Torner, M., Cusí, S., Diedrich, A., Balaguer, P., Gómez-Pujol, L., Álvarez Ellacuria, A., Gómara, S., Sebastian, K., Lora, S., Beltrán, J.P., Renault, L., Juzà, M., Álvarez, D., March, D., Garau, B., Castilla, C., Cañellas, T., Roque, D., Lizarán, I., Pitarch, S., Carrasco, M.A., Lana, A., Mason, E., Escudier, R., Conti, D., Sayol, J.M., Barceló, B., Alemany, F., Reglero, P., Massuti, E., Vélez-Belchí, P., Ruiz, J., Oguz, T., Gómez, M., Álvarez, E., Ansorena, L., Manriquez, M., 2013. SOCIB: The Balearic Islands Coastal Ocean Observing and Forecasting System Responding to Science, Technology and Society Needs. Mar. Technol. Soc. J. 47, 101-117. doi:10.4031/MTSJ.47.1.10.

URL: http://www.ingentaconnect.com/content/mts/mts j/2013/ 00000047/00000001/art00010

Tintoré, J., Wang, D.P., La Violette, P.E., 1990. Eddies and thermohaline intrusions of the shelf/slope front off the northeast Spanish coast. J. Geophys. Res. 95, 1627-1633. doi:10.1029/JC095iC02p01627.

URL: http://onlinelibrary.wiley.com/doi/10.1029/ JC095iC02p01627/pdf

Verron, J., 2013. SARAL/AltiKa: A Ka Band Altimetric Mission. Aviso Users Newsletter 10, 1-15.

URL: http://www.aviso.altimetry.fr/uploads/media/aviso_ special_issue_Saral_news10_01.pdf 
Vignudelli, S., Kostianoy, A., Cipollini, P., Benveniste, J. (Eds.), 2011. Coastal Altimetry. Springer. doi:10.1007/978-3-642-12796-0. ISBN: 978-3-642-12795-3.

URL:

http://link.springer.com/book/10.1007/ 978-3-642-12796-0/page/1

Wang, D.P., Vieira, M.E.C., Salat, J., Tintor, J., La Violette, P.E., 1988. A shelf/slope frontal filament off the northeast spanish coast. J. Mar. Res. 46, 321-332. doi:10.1357/002224088785113586.

URL: http://www. ingentaconnect. com/content/jmr/jmr/1988/ $00000046 / 00000002 /$ art00005

Yoshikawa, Y., Masuda, A., Marubayashi, K., Ishibashi, M., Okuno, A., 2006. On the accuracy of HF radar measurement in the Tsushima Strait. J. Geophys. Res. 111, C04009. doi:10.1029/2005JC003232.

URL: http://onlinelibrary.wiley.com/doi/10.1029/2005JC003232/ abstract 

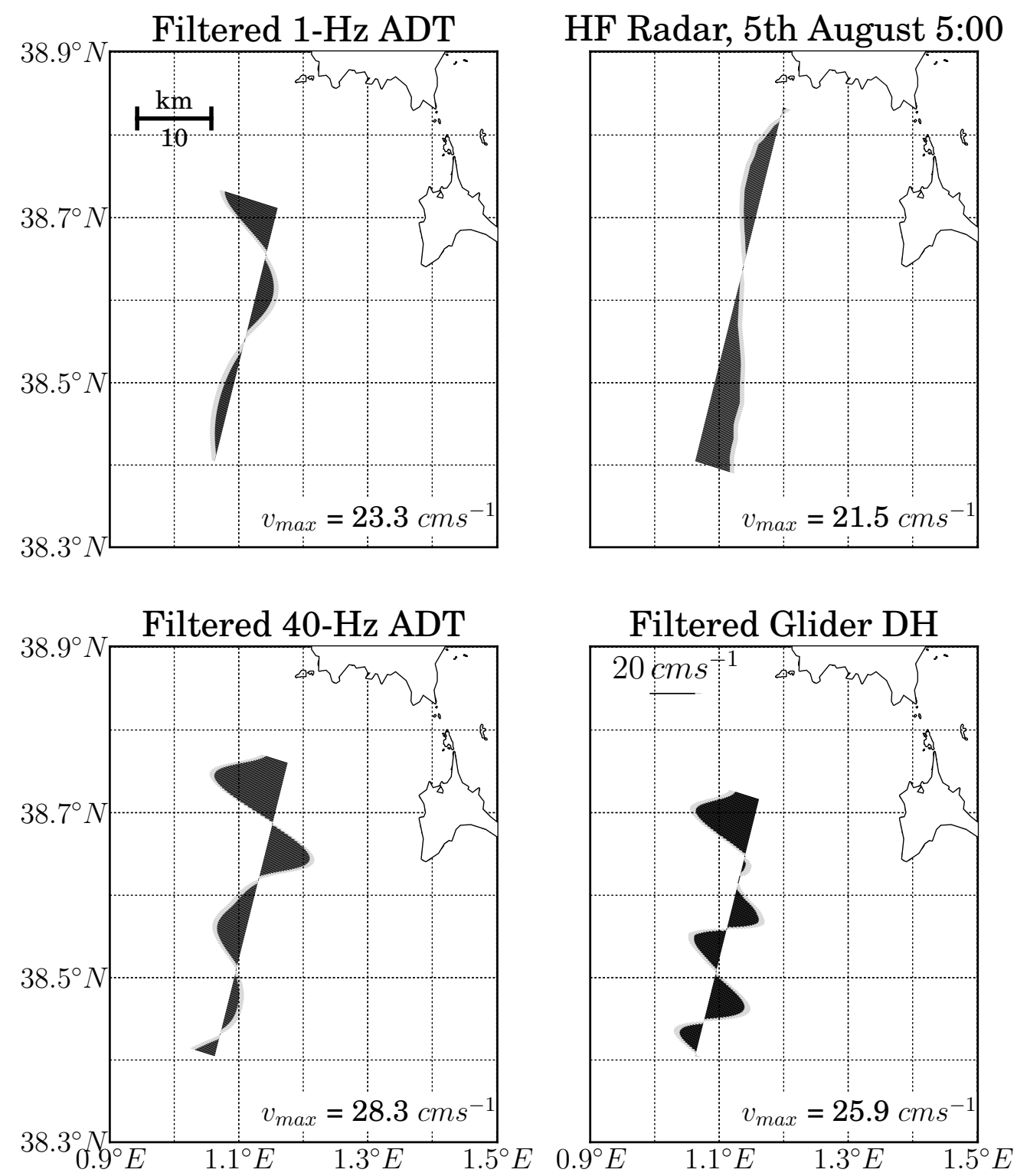

Figure 5: Cross-track velocities obtained by HF radar and by geostrophy for filtered $1 \mathrm{~Hz}$, $40 \mathrm{~Hz}$ and glider data. 